\title{
Do blood components affect the production of reactive oxygen species (ROS) by equine synovial cells in vitro? ${ }^{1}$
}

\author{
Patrícia M. Brossi ${ }^{2}$, Raquel Y.A. Baccarin ${ }^{2 *}$ and Cristina O. Massoco ${ }^{3}$
}

\begin{abstract}
Brossi P.M., Baccarin R.Y.A. \& Massoco C.0. 2012 Do blood components affect the production of reactive oxygen species (ROS) by equine synovial cells in vitro? Pesquisa Veterinária Brasileira 32(12):1355-1360. Departamento de Clínica Médica, Faculdade de Medicina Veterinária e Zootecnia, Universidade de São Paulo, Av. Prof. Dr. Orlando Marques de Paiva 87, Butantã, São Paulo, SP 5508-210, Brazil. E-mail: baccarin@usp.br

Blood-derived products are commonly administered to horses and humans to treat many musculoskeletal diseases, due to their potential antioxidant and anti-inflammatory effects. Nevertheless, antioxidant effects have never been shown upon horse synovial fluid cells in vitro. If proved, this could give a new perspective to justify the clinical application of blood-derived products. The aim of the present study was to investigate the antioxidant effects of two blood-derived products - plasma (unconditioned blood product - UBP) and a commercial blood preparation (conditioned blood product - CBP) ${ }^{4}-$ upon stimulated equine synovial fluid cells. Healthy tarsocrural joints (60) were tapped to obtain synovial fluid cells; these cells were pooled, processed, stimulated with lipopolysaccharide (LPS) or phorbol 12-myristate 13-acetate (PMA), and evaluated by flow cytometry for the production of reactive oxygen species (ROS). Upon addition of any blood-derived product here used - UBP and CBP - there was a significant decrease in the oxidative burst of synovial fluid cells $(\mathrm{P}<0.05)$. There was no difference between UBP and CBP effects. In conclusion, treatment of stimulated equine synovial cells with either UBP or CBP efficiently restored their redox equilibrium.
\end{abstract}

INDEX TERMS: Horse, synovial fluid, plasma, antioxidant, osteoarthritis.

RESUMO.- [Os componentes do sangue afetam a produção de (ERO) pelas células sinoviais de equinos in vitro?] Produtos derivados do sangue são comumente usados, tanto no homem como em cavalos, para tratar diversas doenças musculoesqueléticas, principalmente devido a seus efeitos antioxidantes e anti-inflamatórios. Contudo, efeitos antioxidantes nunca foram demonstrados em células de líquido sinovial in vitro. Caso esses efeitos sejam efetivamente demonstrados, uma nova perspectiva para justificar a aplicação clínica desses produtos poderia surgir.

\footnotetext{
${ }^{1}$ Received on April 30, 2012

Accepted for publication on September 17, 2012

${ }^{2}$ Departamento de Clínica Médica, Faculdade de Medicina Veterinária e Zootecnia (FMVZ), Universidade de São Paulo (USP), Av. Orlando Marques de Paiva 87. Butantã, São Paulo, SP 05508-270, Brazil. *Corresponding author: baccarin@usp.br

${ }^{3}$ Departamento de Patologia, Faculdade de Medicina Veterinária e Zootecnia (FMVZ), Universidade de São Paulo (USP), Avenida Prof. Dr. Orlando Marques de Paiva 87. Butantã, São Paulo, SP 05508-270, Brazil. E-mail: cmassoco@gmail.com

${ }^{4}$ IRAP (Orthogen Veterinary Gmbh, Düsseldorf, Germany).
}

Sendo assim, o objetivo do presente estudo foi investigar os efeitos antioxidantes de dois produtos derivados de sangue - plasma (produto de sangue não condicionado - UBP) e uma preparação comercial de sangue (produto de sangue condicionado - CBP) ${ }^{4}$ - sobre células estimuladas extraídas do líquido sinovial de equinos. Articulações tibiotársicas saudáveis (60) foram puncionadas para a obtenção de células de líquido sinovial; essas células foram concentradas, processadas, estimuladas com lipopolissacarídeos (LPS) ou forbol 12-miristato 13-acetato (PMA), e avaliadas por citometria de fluxo quanto à produção de espécies reativas de oxigênio (ROS). Após a adição de ambos os produtos derivados do sangue - UBP ou CBP - ocorreu uma significativa queda no burst oxidativo em células do líquido sinovial $(\mathrm{P}<0,05)$. Não houve diferença entre os efeitos de UBP e CBP. Em conclusão, tratamento de células estimuladas do líquido sinovial de equinos com UBP ou CBP restaurou eficientemente o equilíbrio redox das células.

TERMOS DE INDEXAÇÃO: Equino, líquido sinovial, plasma, antioxidante, osteoartrite. 


\section{INTRODUCTION}

Osteoarthritis $(\mathrm{OA})$ is characterized by degeneration and loss of articular cartilage and development of new bone on joint surfaces and margins. Reactive oxygen species (ROS) are among the agents implicated in the degradation of cartilage matrix (Henrotin et al. 2003, Petrov et al. 2005) and reduction of synovial fluid viscosity (Greenwald \& Moy, 1980). ROS has been proved to be deleterious to several constituents of the musculoskeletal system (Greenvald \& Moy 1980, Henrotin et al. 2003, Ostalowska et al. 2006). Generation of superoxide and other ROS has been demonstrated in response to inflammatory cytokines and injurious mechanical forces in both equine and human cartilage (Dimock et al. 2000, Regan et al. 2005).

Plasma has been shown to contain several antioxidant systems that counteract the generation of ROS (Sarban et al. 2005, Adib-Conquy \& Cavaillon 2009). It is also a source of growth factors, with potential therapeutic applications (Smith et al. 2006). Recently, autologous blood-derived products such as cell-free autologous conditioned serum (ACS), platelet rich plasma (PRP) and acellular bone marrow aspirate $(\mathrm{ABM})$ have gained special attention for their anti-inflammatory and/or healing enhancing properties. However, their antioxidant effects have not yet been studied but, if demonstrated, could add a new perspective to justify its clinical application.

The objective of the present study was to verify by flow cytometry technique the effects of two blood-derived products on the generation of ROS by synovial fluid cells.

\section{MATERIALS AND METHODS}

\section{Animals}

Thirty eight Standarbred horses, three to ten years of age, fed the same diet, clinically sound (free from lameness and/or joint effusion, with negative flexion tests) and without radiological sign of OA were used. Synovial fluid samples were aseptically collected from 30 horses, left and right tarsocrural joints (60 joints), via a standard dorsomedial approach according to Moyer (2007), to constitute the synovial fluid cell pool.

The remaining horses (8) were used for blood collection, each horse providing two blood samples $(60 \mathrm{~mL})$ to be differently processed, giving origin to two distinct blood-derived products.

Experiments were performed in agreement with the Ethical Principles in Animal Research adopted by Bioethical Commission of the School of Veterinary Medicine and Animal Science of the University of São Paulo (Proc. 1142/2007).

\section{Synovial fluid cell pool preparation}

Immediately after tapping, the synovial fluid sample was transferred to a sterile tube containing EDTA, and kept on ice for no longer than 2 hours, until processing at Laboratório de Farmacologia e Toxicologia do Departamento de Patologia Animal da FMVZ-USP. As normal equine synovial fluid presents low cellularity, which would constrain the analysis, all samples of synovial fluid were pooled to give enough amounts of synovial fluid cells for flow cytometry analysis. The cells were obtained from synovial fluid pool by centrifugation at $300 \mathrm{xg}, 15$ minutes, $4^{\circ} \mathrm{C}$. The cell pellets were washed and resuspended in $2 \mathrm{~mL}$ of phosphate-buffered (PBS). Cellular viability was estimated by Trypan Blue assay. The cells were counted in a Neubauer chamber, and the concentration was adjusted to $1 \times 10^{5}$ cells $/ 100 \mu \mathrm{L}$ in PBS.

\section{Preparation of blood-derived products}

From eight horses, two blood samples were collected according to routine aseptic technique from each horse (16 samples). One sample was drawn in a special $60 \mathrm{~mL}$ syringe, provided by a commercial kit $^{4}$ filled with pre-treated medical beads, as provided by the manufacturer; the other was drawn in regular $60 \mathrm{~mL}$ polypropylene syringes filled with heparin. Both were handled in the same manner: blood was incubated in the syringes at $37^{\circ} \mathrm{C}$ for 24 hours with $5 \% \mathrm{CO}_{2}$ in a horizontal position, and centrifuged at $600 \mathrm{xg}$ for 10 minutes to yield a plasma-like product.

The final product obtained with the syringe provided in the commercial kit will be referred to as conditioned blood product (CBP) and the one obtained through regular syringes as unconditioned blood product (UBP). After filtration through a $0.22 \mu \mathrm{m}$ micro filter, $2 \mathrm{~mL}$ aliquots were stored at $-20^{\circ} \mathrm{C}$ until used. At the moment of use, each aliquot was diluted 1:5 in PBS.

\section{Measurement of oxidative burst}

The following reagents were used to stimulate oxidative burst: (1) phorbol 12-myristate 13- acetate (PMA) (Sigma, St Louis, MO), $1 \mathrm{mg} / \mathrm{mL}$ in ethanol, stored at $-20^{\circ} \mathrm{C}$. It was used to prepare, at the moment of use, a $100 \mathrm{ng} / \mathrm{mL}$ solution in PBS; (2) lypopoolysaccharide (LPS)(strand 055:B55, Sigma, St Louis, MO ), $1 \mathrm{mg} / \mathrm{mL}$ in PBS, stored at $-20^{\circ} \mathrm{C}$. It was used to prepare, at the moment of use, a $10 \mu \mathrm{g} / \mathrm{mL}$ solution in PBS. The fluorescent dye used was dichlorofluorescein diacetate (DCFH-DA, Molecular Probes) at a final concentration of $0.3 \mathrm{mM}$. DCFH-DA diffuses into the cells and is hydrolyzed to the non-fluorescent 2'7'-dichlorofluorescein (DCFH) during the polymorphonuclear cells oxidative burst. Intracellular DCFH is oxidized to highly fluorescent dichlorofluorescein (DCF) by peroxidase and $\mathrm{H}_{2} \mathrm{O}_{2}$. DCF then emits a fluorescent signal that is measured by flow cytometer.

\section{Generation of reactive oxygen species (ROS) and flow cyto- metry}

The oxidative burst assays for equine synovial fluid cells were performed according to Massoco et al. (2006). Control sample (negative controls) contained $1 \times 10^{5}$ synovial cells (in $100 \mu \mathrm{L}$ suspension), $200 \mu \mathrm{L}$ of DCFH-DA and $700 \mu \mathrm{L}$ of sterile PBS (without stimulants), in $1 \mathrm{~mL}$ final volume. These samples were incubated in water bath at $37^{\circ} \mathrm{C}$ for 20 minutes, giving the basal levels of ROS production. To evaluate the stimulated oxidative burst, identical incubation mixtures were prepared, containing the same number of cells, and the incubation with DCFH-DA was followed by incubation with $100 \mu \mathrm{L}$ of either PMA or LPS. To analyze the effects of two blood-derived products, $200 \mu \mathrm{L}$ of CPB or UPB were added to cells loaded with DCFH, and with or without stimulants, followed by PBS volume to reach a $1 \mathrm{~mL}$ final volume and incubating under the same conditions. Other dilutions of CPB and UPB were used on pilot experiments (data not shown) and the lowest dilution which had anti-oxidant effects were used (1:5).

The cells were collected by centrifugation (300xg, $10 \mathrm{minu}-$ tes, $4^{\circ} \mathrm{C}$ ), and the supernatant was discarded. Contaminating erythrocytes were removed by hypotonic lysis with $2 \mathrm{~mL}$ of $0.2 \%$ $\mathrm{NaCl}$ for 20 seconds, followed by washing with $2 \mathrm{~mL}$ of $1,6 \% \mathrm{NaCl}$ to restore isotonicity. Samples were again centrifuged (300xg, 10 minutes, $4^{\circ} \mathrm{C}$ ), and finally the cells were resuspended in $300 \mu \mathrm{L}$ of PBS and analyzed by flow cytometry (FacsCALIBUR, Benton Dickinson Immunocytometry Systems). Samples were evaluated in triplicates.

Cells were gated on the basis of their characteristic morphology, i.e. characteristic of granularity (side scatter) and size (forward scatter) of leukocytes and acquired in a flow cytometer using the Cell Quest Pro software (Becton Dickinson). Green mean 

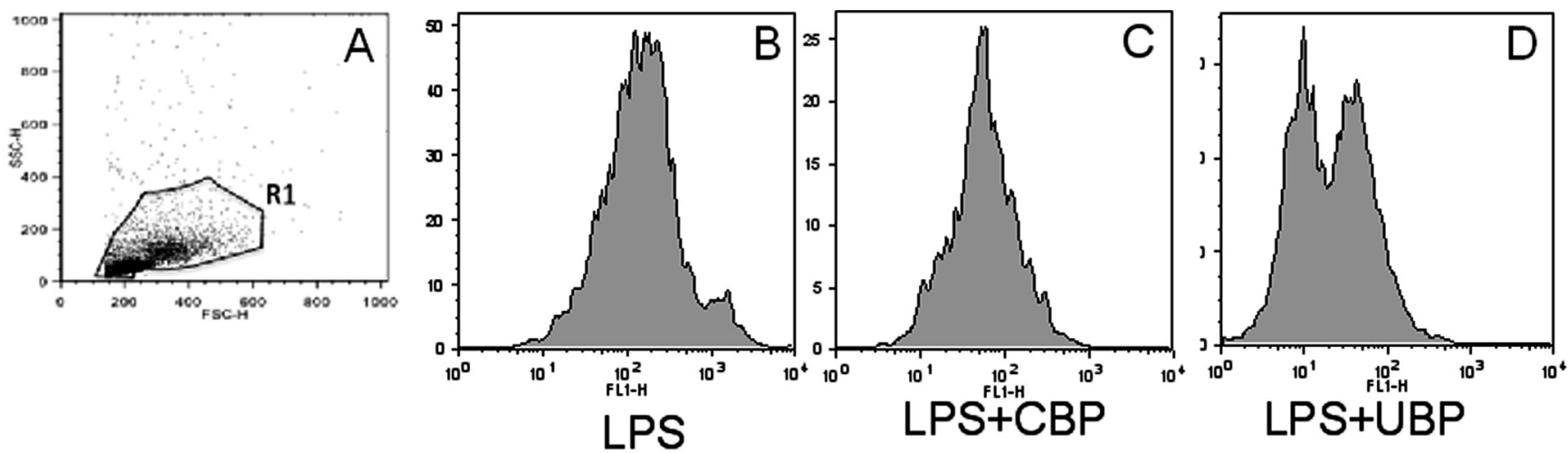

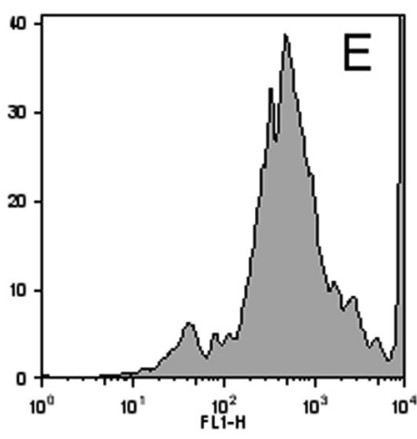

PMA

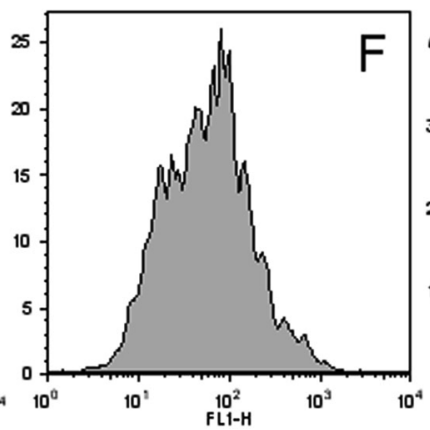

$\mathrm{PMA}+\mathrm{CBP}$

fluorescence was recorded as oxidative burst. Data from 10.000 events were collected excluding the lymphocyte population. Mean intensity of fluorescence after oxidation was evaluated. Samples were evaluated in triplicates.

Barlett's test showed that data concerning oxidative burst were parametric, and thus, one-way Analysis of Variance comparison of means of cellular fluorescence was employed. The Instat Statistic Analysis Package was used and the level of significance set at $P<0.05$.

\section{RESULTS}

\section{Oxidative burst response in synovial cells}

Flow citometry data on figure $1 \mathrm{~A}$ showed leukocytes and synovial cells identified by typical side scatter (SSC) versus forward scatter (FSC) cytogram of equine synovial fluid. This figure is representative of equine synovial cellular pool and revealed mononuclear (MNC) (synoviocytes, monocytes and macrophages) and polymorphonuclear cell population (PMN) (neutrophil) that was gated according to their granularity and size (R1) thus excluding debris cellular of analysis. Based on this cytogram we could set histograms where the more green fluorescence a cell emits (corresponding to more ROS), the farther to the right the cell data will appear on the histogram. Figure 1B-G shows a measurement of green mean fluorescence witch is representative of oxidative burst of DCFH-loaded MNC and PMN cells after incubation with stimulants and blood-derived products preparation.

Even though PMA stimulated synovial fluid cells with greater magnitude, both stimulants PMA and LPS were efficient in inciting oxidative burst. The mean intensity of fluorescence emission was significantly increased $(P=0.03)$ in synovial fluid cells after the addition of PMA $(325.11 \pm 0.1)$

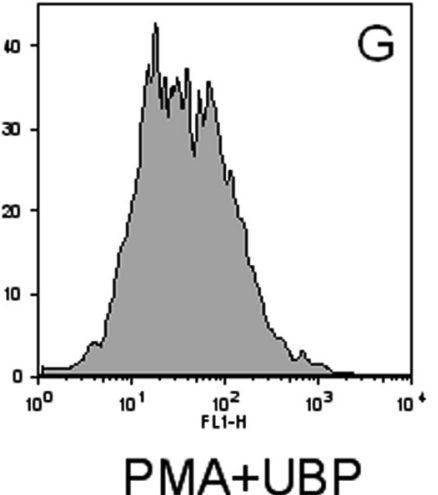

Fig1. Analysis of the oxidative burst based on forward and side scatter cytograms (FSC/SSC) (A) and fluorescence channel histograms (X-axis is the amount of green fluorescence), corresponding to DCFH fluorochrome of representative in vitro incubation: LPS (B); PMA (C); LPS plus CBP (D); LSP plus UBP (E); PMA plus CBP (F); PMA plus $\operatorname{UBP}(\mathbf{G})$.

or LPS (131.43 \pm 0.1$)$ when compared with basal level (93.49 \pm 01 ) (Fig.2).

Both blood-derived products -UBP and CBP- significantly decreased the mean intensity of ROS production, causing equivalent decreases in the intensity of the respiratory burst, irrespectively of the stimulating agent (PMA or LPS). UBP decreased the mean fluorescence induced by PMA to $47.37 \pm 4.8$, and by LPS to $30.72 \pm 2.39$ ( $\mathrm{P}<0.05$ ). CBP decreased the mean fluorescence stimulated by PMA to $45.92 \pm 10.19$, and by LPS stimulation to $58.28 \pm 12.37$ $(\mathrm{P}<0.05)$ (Fig.2)

\section{DISCUSSION}

Several studies have been performed on the mechanisms through which blood-derived products can achieve the-

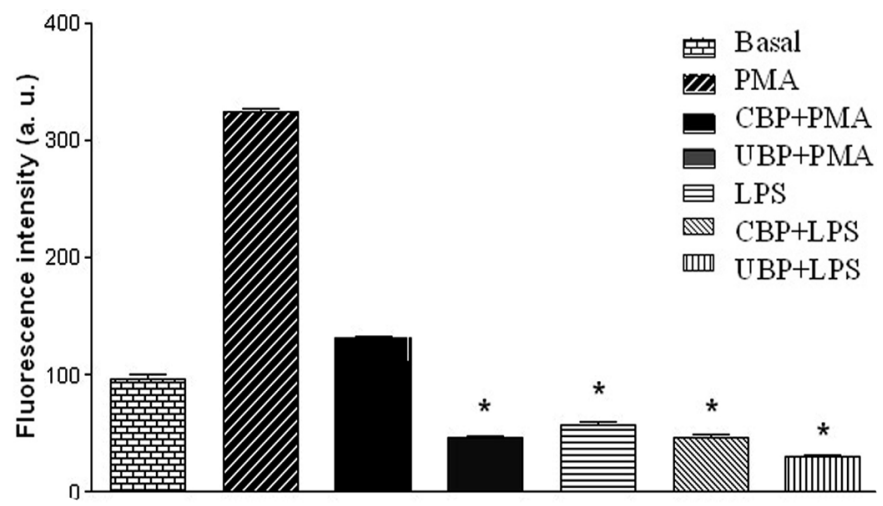

Fig.2. Comparison of the effects of CBP and UBP samples on mean fluorescence intensity of equine synovial fluid cells incubated without (basal) or with LPS and PMA. Results are expressed as geometric mean \pm SD. 
rapeutic effects on orthopedic lesions. However, the up to now identified mechanisms seem to come in play at a later stage of the inflammatory or healing process (Schnabel et al. 2008, Sutter 2007), and studies on their effects on redox imbalances have not yet been done.

In the present study, we have shown that synovial fluid cells stimulated with either PMA or LPS presented in intense production of ROS, mimicking the response to an acute injury. The fast response points towards the involvement of constitutive, intrinsic mechanisms or agents (Bours et al. 2006).

Both blood-derived preparations, CBP and UBP, have shown antioxidant properties, probably through restoration of redox balance after the PMA and LPS challenge.

Our results also show that the commercial device (glass beads) used to prepare CBP was not necessary to produce the antioxidants response, since UBP (plasma) led to similar results. The premise that the special syringe designed for blood collection may play a role in whole blood stimulation and generation of antioxidant substances was not confirmed in our experiment. It is also possible that other factors, such as interaction of blood with artificial surfaces, time of incubation, temperature, etc., could also be stimulating factors.

Corroborating these findings, it was recently shown that the levels of anti-inflammatory cytokines - interleukin 1 receptor antagonist (IL-1ra), interleukin 10 (IL-10) and tumor growth factor- $\beta$ (TGF- $\beta$ ) - were the same in blood-derived products obtained by incubation of whole blood with either specially customized syringes containing glass beads or regular glass red-top Vacutainer tubes. Only for insulin-like growth factor-1 (IGF-1), the incubation of blood in the customized syringes led to significantly increased growth factor production (Hrara et al. 2011).

The contact of blood with artificial surfaces is known to induce an inflammatory response, with activation of leukocytes and platelets, as well as complement and other plasma cascade systems. In this sense, the stimulatory action of medical-grade glass on whole blood during incubation reported by Meijer et al. (2003) is the principle behind the concept of the special syringe. Other materials, such as polyvinylchloride (PVC), induce a substantial increase in leukotriene B4, prostaglandin E2 and thromboxane B2, after incubation of blood for 4 hours and activate complement system, primarily through the alternative pathway (Lappegard et al. 2005). The effects of PVC-induced IL-1 $\beta$ and IL-10 have also been described (Lappegard et al. 2004).

As contact stimulation with glass beads in the commercial device was not responsible for increased anti-inflammatory cytokine production other factors must play a part. Another variable, length of incubation, has been shown to play an important role in cytokine production (Jansky et al. 2003). Also, the relatively long incubation time of blood-derived products used in this experiment ( 24 hours) was shown to be necessary for some of the anti-inflammatory cytokines to induce its effects (Gallová et al. 2004) and as demonstrated by Bussolati et al. (1997), incubation of monocytes and polymorphonuclear leukocytes with IL-10 for 24 hours before stimulation, decreased superoxide produc- tion as a late effect, in despite of an early increment in ROS production observed in the first hours of incubation (Remick et al. 2000).

Effects of plasma and serum on the oxidative burst of blood polymorphonuclear leukocytes (PMNLs) have been already described (Lanser et al. 1986, Zimmerman et al. 1989, Pascual et al. 1998, Fumeaux et al. 2004). They can be contradictory depending on the source of plasma: plasma or serum from septic/trauma patients had a depressant effect on the generation of ROS by stimulated PMNLs from a healthy donor (Pascual et al. 1998); conversely, plasma from normal patients significantly enhanced the phagocytic capacity and ROS generation in PMNLs from septicemic patients (Wenisch \& Graninger 1995). These studies implicated IL-10 and IL-1ra as the main anti-inflammatory mediators, responsible for diminished ROS generation (Pascual et al. 1998, Fumeaux et al. 2004, Adib-Conquy \& Cavaillon, 2009). According to Frisbie et al. (2006) synovial fluid concentration of IL-1ra was increased following treatment with autologous conditioned serum.

Indeed, culture of whole blood for 24 hours was found to significantly increase production the anti-inflammatory cytokines IL-10 and IL-1ra independent of treatment of blood, indicating that up regulation was a consequence of incubation time rather than treatment. More than that, the increase was of equal statistic significance between treatments. When cytokine production was observed with only one hour of incubation, IL-1ra and IL-10 levels were significantly lower (Hraha et al. 2011).

On the nature of the antioxidant blood component(s), IL-10 seems to be one of the most attractive alternatives to explain the observed reduction in PMN and MNC oxidative burst in this experiment. IL-10 has been shown to be related to plasma's depressant effect on ROS production (Bussolati et al. 1997, Dang et al. 2006) in a similar fashion to our results; its anti-inflammatory effects on human neutrophil respiratory burst involves inhibition of proper functioning of the enzyme nicotinamide adenine nucleotide phosphate oxidase (NADPH) (Dang et al. 2006).

NADPH is dormant in non-activated cells, and its components in the resting state are present in two different compartments, the plasma membrane and the cytosol (Vignais 2002). Inhibition of phosphorylation of one of its cytosolic subunits, $\mathrm{p} 47^{\text {PHOX }}$ through a decrease in extracellular signal regulated kinase $1 / 2$, is the mechanism responsible for the impairment in enzyme function. Phosphorylation of the cytosolic component $\mathrm{p} 47^{\text {PHOX }}$ is one of the key intracellular events associated with NADPH oxidase activation, and is essential for the conformational changes that will initiate formation of the active oxidase. Dang et al. (2006) were able to demonstrate the inhibitory effect of IL-10 on p47 ${ }^{\text {PHOX }}$ phosphorylation and ERK $1 / 2$ activity 20 minutes after incubation of freshly isolated PMNs with IL-10. The intracellular signaling pathways initiating these events must thus, occur early (Dang et al. 2006). In the present experiment one of the striking observations regarding the antioxidant effect of conditioned and unconditioned blood products was its rapid onset. Rapid inactivation of NADPH oxidase could be due to several processes, including recep- 
tor desensitization, uncoupling of transduction pathways and modulation of the phosphorylation of NADPH oxidase components, such as p47 ${ }^{\text {PHOX }}$ and p67 ${ }^{\text {PHOX }}$, and would explain rapid inhibition of the oxidative burst.

These properties, together with the extremely favorable conditions for its production, turn IL-10 into a suitable candidate for the soluble factor present in the blood-derived products in this experiment, responsible for the fast down regulation of PMN's respiratory burst.

Another plausible candidate for the plasma soluble factor responsible for decreasing ROs production would be IL- $1 \mathrm{ra}$, as it blocks the action of IL- $1 \alpha$ and IL- $1 \beta$ ligands by competitive inhibition at the IL-1 receptor level, in vitro and in vivo (Dinarello 1998). IL-1 antagonism through occupation of its receptor is capable of reducing ROS production, as IL-1's role in ROS generation have already been demonstrated by Davies et al (2008).

IL-1ra is produced by monocytes and macrophages after LPS stimulation in human volunteers (Dinarello 1998) and is also induced by in vitro exposure of whole blood to chromium sulphate or borosilicate treated glass beads, as in the syringes provided in the commercial kit employed; with this processing a 140 -fold increase in IL-1ra is observed after a 24 hour incubation period, due to its de novo production (Frisbie et al. 2006).

Although the present study does not yield information on the specific antioxidant component(s) present in the blood-derived products used as treatments, it clearly shows that their production is not related to the physical device provided by the commercial kit, but to the steps adopted in blood processing. The magnitude of this antioxidant generation is sufficient to significantly inhibit ROS generation incited by all stimuli employed here. Another particular feature of this experiment is that it compares the performance of the conditioned and the unconditioned blood products regarding their potential as antioxidant therapies, clarifying the effects (or lack of) of this "conditioning".

Whatever the main anti-inflammatory cytokines present in CBP and UBP are, the remarkable effect associated with their up regulation is the rapid induction of inhibition of the respiratory burst of PMNs from equine synovial cells fluid challenged with classical pro-inflammatory stimulants observed in this experiment.

This effect has not been demonstrated before for blood-derived products intended for use in musculoskeletal injuries, although free radicals as mediators of joint, tendon and ligament dysfunctions and antioxidants, as tools to counteract their actions, have been extensively studied (Greenwald \& Moy, 1980, Bates et al. 1984, Henrotin et al. 2003, Regan et al. 2005, Loeser 2006, Davies 2008).

Blood-derived products tested here would be a favorable intervention in the genesis of ROS-mediated tissue damage, by being able to neutralize the enzyme responsible for it.

\section{CONCLUSION}

Plasma (UBP) exhibited an in vitro antioxidant effect on cells from synovial fluid, as evidenced by its ability to markedly reduce the generation of free radicals by synovial leukocytes. This effect was statistically equivalent to the one exerted by a commercial blood preparation. The results observed in vitro should encourage clinical trials to determine if plasma has antioxidant effects in vivo on cells of the synovial fluid, and if these effects have clinically observable effects on suppressing joint inflammation.

\section{REFERENCES}

Adib-Conquy M. \& Cavaillon J. 2009. Compensatory anti-inflammatory syndrome. Thromb. Haemost. 101:36-47.

Bates E.J., Lowther D.A. \& Handley C.J. 1984. Oxygen free-radicals mediate an inhibition of proteoglycan synthesis in cultured articular cartilage. Ann. Rheum. Dis. 43:462-469.

Bours M.J.L., Swennen E.B.L.R., Di Virgilio F., Cronstein B.N. \& Dagnelie P.C. 2006. Adenosine 5'-triphosphate and adenosine as endogenous signaling molecules in immunity and inflammation. Pharmacol. Therapeut. 112:358-404.

Bussolati B., Mariano F., Montrucchio G., Piccoli G. \& Camussi G. 1997. Modulatory effect of interleukin-10 on the production of platelet-activating factor and superanions by human leukocytes. Immunology 90:440-447.

Dang P.M., Elbim C., Marie J.C., Chiandotto M., Gougerot-Pocidalo M. \& El-Benna J. 2006. Anti-inflammatory effect of interleukin-10 on human neutrophil respiratory burst involves inhibition of GM-CSF-induced p47 phox phosphorylation through a decrease in ERK1/2 activity. FASEB J. 20:E698-E709.

Davies C.M., Guilak F., Weinberg J.B. \& Fermor B. 2008. Reactive nitrogen and oxygen species in interleukin-1 me4diated DNA damage associated with osteoarthritis. Osteoarthr. Cartilage16:624-630.

Dimock A.N., Siciliano P.D. \& McIlwraith C.W. 2000. Evidence supporting an increased presence of reactive oxygen species in the diseased equine joint. Equine Vet. J. 32:439-443.

Dinarello C.A. 1998. Interleukin-1, interleukin-1 receptors and interleukin-1 receptor antagonist. Int. Rev. Immunol. 16:457-499.

Frisbie D.D., Kawcak C.E., Werpy N.M., Park R.D. \& McIlwraith C.W. 2006. Clinical, biochemical, and histologic effects of intra-articular administration of autologous conditioned serum I horses with experimentally induced osteoarthritis. Am. J. Vet. Res. 68:290-296.

Fumeaux T., Dufour J., Stern S. \& Pugin J. 2004. Immune monitoring patients with septic shock by measurement on intraleukocyte cytokines. Intens. Care Med. 30:2028-2037.

Gallová L., Kubala L., Ciz M. \& Lojek A. 2004. IL-10 Does not affect burst and expression of selected surface antigen on human blood phagocytes in vitro. Physiol. Res. 53:199-208.

Greenwald R.A. \& Moy W.W. 1980. Effect of oxygen-derived free radicals on hyaluronic acid. Arthritis Rheum. 23:455-463.

Hraha T.H., Doremus K.M., McIlwraith C.W. \& Frisbie D.D. 2011. Autologous conditioned serum: The comparative cytokine profiles of two commercial methods (IRAP and IRAP II) using equine blood. Equine Vet. J. 43:516-521.

Henrotin Y.E., Bruckner P. \& Pujol J.-P.L. 2003. The role of reactive oxygen species in homeostasis and degradation of cartilage. Osteoarthr. Cartilage 11:747-755.

Jansky L., Reymanová P. \& Kopecky J. 2003. Dynamics of cytokine production in human peripheral blood mononuclear cells stimulated by LPS or infected by Borrelia. Physiol.Res. 52:593-598.

Lappegard K.T., Fung M., Bergseth G., Riesenfeld J. \& Mollnes T.E. 2004. Artificial surface-induced cytokine synthesis: effect of heparin coating and complement inhibition. Ann. Thorac. Surg. 78:38-45.

Lappegard K.T., Riesenfeld J., Brekke O., Bergseth G., Lambris J.D. \& Mollnes T.E. 2005. Differential effect of heparin coating and complement inhibition on artificial surface-induced eicosanoid production. Ann. Thorac. Surg.79:917-923.

Lanser M.E., Brown G.E., Mora R., Coleman W. \& Siegel J.H. 1986. Trauma serum suppresses superoxide production by normal neutrophils. Arch. Surg. 121:157-162. 
Loeser R.F. 2006. Molecular mechanisms of cartilage destruction: mechanics, inflammatory mediators and aging collide. Arthritis Rheum. 54:1357-1360.

Meijer H., Reinecke J., Becker C., Tholen G. \& Wehling P. 2003. The production of anti-inflammatory cytokines in whole blood by physic-chemical stimulation. Inflamm. Res. 52:404-407.

Moyer W., Schumacher J. \& Schumacher J. 2007. A Guide to Equine Joint Injection and Regional Anesthesia: Veterinary learning systems, Yardley, Pennsylvania. 111p.

Ostalowska A., Birkner E., Wiecha M., Kasperczyk S., Kasperczyk A., Kapolka D. \& Zon-Giebel A. 2006. Lipid peroxidation and antioxidant enzymes in synovial fluid of patients with primary and secondary osteoarthritis of knee joint. Osteoarthr. Cartilage 14:139-145.

Pascual C., Bredle D., Karzai W., Meier-Hellmann A., Oberhoffer M. \& Reinhart K. 1998. Effect of plasma and LPS on respiratory burst of neutrophils in septic shock. Intens. Care Med. 24:1181-1186.

Petrov R., MacDonald M.H., Tesch A.M. \& Benton H.P. 2005. Inhibition of adenosine kinase attenuates interleukin-1 and lipopolysaccharide-induced alterations in cartilage metabolism. Osteoarthr. Cartilage 13:250257.

Regan E., Flannelly J., Bowler R., Tran K., Nicks M., Carbone B.D., Glueck D., Heijnen H., Mason R. \& Crapo J. 2005 Extracellular superoxide dismu- tase and oxidant damage in osteoarthritis. Arthritis Rheum. 52:34793491.

Remick D.G., Newcomb D.E. \& Friedland J.S. 2000. Whole-Blood assays for cytokine production. Methods Mol. Med. 36:101-112.

Sarban S., Kocygit A., Yazar M. \& Isikan U.E. 2005. Plasma total antioxidant capacity, lipid peroxidation, and erythrocyte antioxidant enzyme activities in patients with rheumatoid arthritis and osteoarthritis. Clin. Biochem. 38:981-986.

Schnabel L.V., Mohammed H.O., Jacobson M.S. \& Fortier L.A. 2008. Effects of platelet rich plasma and acellular bone marrow on gene expression patterns and DNA content of equine suspensory ligament explants cultures. Equine Vet. J. 40:260-265.

Sutter W.W. 2007. Autologous cell-based therapy for tendon and ligament injuries. Clin. Tech. Equine Pract. 6:198-208.

Vignais P.V. 2002. The superoxide-generating NADPH-oxidase: Structural aspects and activation mechanisms. Cell Mol. Life Sci. 59:1428-1459.

Wenisch C. \& Graninger W. 1995. Are soluble factors relevant for polymorphonuclear leukocyte dysregulation in septicemia? Clinical and diagnostic laboratory. Immunology 2:241-245.

Zimmerman J.J., Millard J.R. \& Farrin-Rusk C. 1989. Septic plasma suppresses superoxide anion synthesis by normal homologous polymorphonuclear leukocytes. Crit. Care Med. 17:1241-1246. 